\title{
Geoscientific Characterization and Interpretation (Geosynthesis) within the Preliminary Safety Assessment in the German Site-Selection Procedure for a High-level Nuclear Waste Repository
}

\author{
Sönke Reiche, Reinhard Fink, and Nils-Peter Nilius \\ Bundesgesellschaft für Endlagerung mbH, 31224 Peine, Germany \\ Correspondence: Sönke Reiche (soenke.reiche@bge.de) \\ Published: 10 November 2021
}

\begin{abstract}
After implementation of the Repository Site Selection Act (StandAG) in 2017, the Federal Company for Radioactive Waste Disposal (BGE), as the German waste management organization, started the site selection procedure for a nuclear repository for high-level radioactive waste in Germany. On the way towards the repository site with the best possible safety, the site selection procedure is required to be a participatory, transparent, learning and self-questioning process based on scientific expertise. With the Subareas Interim Report published in 2020, first results were presented outlining subareas with favourable geological conditions in preparation for defining the siting regions for surface exploration.

Currently, one of the main tasks in the site selection procedure is to establish a detailed geoscientific synthesis (Geosynthesis) for each subarea. The Geosynthesis contains all geological information for the characterization of each subarea and hence serves as the foundation for the subsequent analysis within the representative preliminary safety assessments (rvSU) and the geoscientific consideration criteria. Based on this information, all areas within the subareas will be evaluated to find the siting regions for surface exploration.

The Geosynthesis includes a description of the regional geology focusing on the host rock, the overburden and relevant geological processes that may affect the potential nuclear waste repository in the next 1 million years. The data for the Geosynthesis are mostly compiled from state authorities and include 3-D geologic models, regional maps and cross-sections, bore hole data (e.g. geophysical logs) and seismic data. Furthermore, it is necessary to digitize, process, interpret and evaluate the aforementioned data using the available knowledge from the scientific literature in the context of the site selection procedure.
\end{abstract}

Kurzfassung. Nach Inkrafttreten des Standortauswahlgesetzes (StandAG) im Jahr 2017 begann die Bundesgesellschaft für Endlagerung (BGE) als Vorhabenträgerin des Standortauswahlverfahrens mit der Suche nach einem Standort für die Endlagerung hochradioaktiver Abfälle in Deutschland. Auf dem Weg zu einem Endlagerstandort mit der bestmöglichen Sicherheit muss das Standortauswahlverfahren ein partizipativer, transparenter, lernender, wissenschaftsbasierter und sich selbst hinterfragender Prozess sein. Mit der Veröffentlichung des Zwischenberichts Teilgebiete im Jahr 2020 wurden erste Ergebnisse vorgestellt und darin Teilgebiete mit günstigen geologischen Voraussetzungen in Vorbereitung auf die Ermittlung von Standortregionen für die übertägige Erkundung benannt.

Aktuell besteht eine der Hauptaufgaben beim Standortauswahlverfahren darin, eine detaillierte geowissenschaftliche Synthese (Geosynthese) für jedes Teilgebiet zu erstellen. Die Geosynthese enthält sämtliche geologischen Informationen für die Charakterisierung jedes Teilgebiets und dient daher als Grundlage für die anschließende Auswertung im Rahmen der repräsentativen vorläufigen Sicherheitsuntersuchungen (rvSU) und der geowissenschaftlichen Abwägungskriterien. Auf Grundlage dieser Informationen werden alle Gebiete innerhalb der Teilgebiete untersucht, mit dem Ziel, Standortregionen für die übertägige Erkundung zu ermitteln. 
Die Geosynthese enthält eine Beschreibung der regionalen Geologie mit Fokus auf dem Wirtsgestein, dem Deckgebirge und den relevanten geologischen Prozessen, die ein potenzielles Endlager in den nächsten 1 Mio. Jahren betreffen können. Dabei stammen die Daten für die Geosynthese zum überwiegenden Teil von den Staatlichen Geologischen Diensten und umfassen auch geologische 3D-Modelle, geowissenschaftliche Karten und Profilschnitte, Bohrlochdaten (z. B. geophysikalische Bohrlochmessungen) und seismische Daten. Die zuvor genannten Daten werden im Rahmen des Standortauswahlverfahrens digitalisiert, aufbereitet, und unter Einbeziehung wissenschaftlicher Literatur interpretiert. 